\title{
Unofficial geographies of religion and spirituality as postsecular spaces
}

Book or Report Section

Accepted Version

Wigley, E. (2018) Unofficial geographies of religion and spirituality as postsecular spaces. In: Beaumont, J. (ed.) The Routledge Handbook of Postsecularity. Routledge, London and New York, pp. 371-382. ISBN 9781138234147 Available at http://centaur.reading.ac.uk/81953/

It is advisable to refer to the publisher's version if you intend to cite from the work. See Guidance on citing.

Published version at: https://www.routledge.com/The-Routledge-Handbook-of-

Postsecularity/Beaumont/p/book/9781138234147

Publisher: Routledge

All outputs in CentAUR are protected by Intellectual Property Rights law, including copyright law. Copyright and IPR is retained by the creators or other copyright holders. Terms and conditions for use of this material are defined in the End User Agreement. 


\section{www.reading.ac.uk/centaur}

\section{CentAUR}

Central Archive at the University of Reading

Reading's research outputs online 


\section{Unofficial geographies of religion and spirituality as postsecular}

\section{spaces}

Edward Wigley

\section{Introduction}

Since the early 2000s, geographers have been encouraged to investigate religious experience and spirituality 'beyond the official' spaces of institutionalized religion (Kong 2001). What is 'official' is often constituted by the spaces sanctioned for religious purpose, practice, symbolism, and expression by governmental or specific organizations perceived to have legal or social authority. To be 'unofficial' is considered that which is not sanctioned by, and in some cases even resisted by, local authorities or religious organizations and groups. Western societies are increasingly resisting official narratives, and schemes of social organization are moving towards unofficial actions and praxis as part of the 'massive subjective turn of society' (Taylor 1991, cited in Heelas and Woodhead 2005).

Meanwhile the postsecular agenda has suggested a plurality of different channels in which religion has infiltrated popular, and 'secular', appropriations of discourses and spaces (Molendjik et al 2010; Beaumont and Baker 2011; Beckford 2012). These different channels can be seemingly dramatic and dominant, such as the return of religion via fundamentalist groups (Wilson and Steger 2013), or less visible through faith-based organizations and groups providing social or public services without emphasizing their religious identities through symbolism or codification (Dalferth 2010; Beckford 2012; Cloke and Beaumont 2013; Reynolds 2015) as well as the continuing and affecting prevalence of religious identities of people and sites (Knott 2010; Stevenson et al. 2010; Havlicek and Klingorova 2017). 
This contribution considers the postsecular in the light of the subjectivization of religion and emergence of spirituality. More specifically it draws on empirical research to focus on the subjective experience and construction of geographies that maybe framed as postsecular: the non-institutional and non-religiously coded everyday urban spaces that can accommodate, through the acts of contemplation, practice, and mobility, sacred spaces within the profane. Such experiences often draw from the official institutions and narratives of religion, but blend these sources into unofficial spaces of home, employment, recreation, and journeys. The next section will first consider the literatures investigating geographies of religion and spirituality and the mobilities paradigm before relating these to contemporary discussions of the postsecular. Following this will be a discussion drawing on the author's empirical research. This work demonstrates the postsecular within the context of the individual's everyday life and activities, and how this is understood on a practical and aesthetic level. The entry then concludes that such practices as they merge into everyday life, 'spiritually re-appropriate' (Beaumont and Baker 2011) secular landscapes on a personal, rather than institutional or organizational, scale.

\section{The postsecular}

Postsecularity emerged during the early twenty-first century, employing a range of definitions and being deployed as a concept in a range of different discursive contexts (Molendjik et al. 2010; Beckford 2012; Olson et al. 2013). Definitions have been diverse; however, there are common themes to the different interpretations of the postsecular. While some commentators have suggested that the term implies the decline of the secularization narrative and resurgence of the religion in Western societies where secularization is understood to have taken place in the twentieth century (Bruce 2013), this does not represent the majority of views. The 'established' churches of Western Europe continue to decline. In the UK, the Church of England as well as the 
Methodist Churches continues to dramatically reduce in numbers decade after decade. Religions that have seen growth are those that became an established presence in the last half of the twentieth century, with a clear (often conservative) theological message and/or a core base within migrant communities and their children rather than a resurgence among those communities who had previously abandoned their churches (Parsons 1993; Davie 2006; Guest et al. 2012).

Religion never really disappeared in the way that the sociologists of the twentieth century predicted (Woodhead 2012; Davie 2015). Beliefs and practices became fragmented and disassembled from larger structures of religious institutions, instead finding more individually orientated models of 'spirituality' (Davie 1994; Heelas and Woodhead 2005). The late twentieth century saw the growth of participation in 'New Age' or alternative spiritualities or activities and their wider diffusion across different and diverse segments of society, from business offices that accommodate massage practitioners to aromatherapy candles available in supermarkets (Heelas and Woodhead 2005; Harvey and Vincent 2012). Alongside this prevalence of 'spirituality' has been the political presence of religion in institutional and popular forms identified by many postsecular studies. Recent social and political developments have drawn religious organizations into the public sphere in more 'official' capacities. In the UK, for example, the economic measures and political drive through the short-lived 'Big Society' ideology, has seen increased visibility of Christian and non-Christian faith-based organizations delivering public and social services such as adoption agencies and food banks (Cloke 2011). Such shifts are driven by a lack of concern regarding, or downplaying of, the faith- or non-faith-based motivation of an organization or group, provided that the outcomes are delivered and accessible to all faiths and none (Dalferth 2010; Cloke and Beaumont 2013). For the organizations and groups delivering 
such services, their new-found role represents an opportunity to reclaim a position of importance in the public sphere - a reterritorialization of the neoliberal and urban society (Beaumont and Baker 2011).

Cities, as seen earlier, have been critical spaces for the emergence of postsecular communities, whether in the delivery of public services, the co-existence and contestation between different faiths and none (Fenster 2011; Olson et al. 2013), and the complexities of decline and growth within Christian and non-Christian religions (Stevenson et al. 2010). Reterritorialization of political and social spaces is a key concern in this debate; however, it is the transformation of religious praxis and emergence of 'spirituality' that people perform consciously and unconsciously that is examined in this essay. Knott (2005) presents a possible pathway when considering the multiple spatial properties of objects and their relationships between the religion, the secular, and the postsecular. Meanings are generated by the juxtapositions of particular symbols, objects, or people in different spaces, and the recombination of these things create, reinforce, or challenge values associated with places.

The manifestation of religion or spirituality in spaces outside of official sites therefore generates new meanings or challenges or confirms other values. This concern for understanding the individual at the centre of processes of the postsecular coincides with Zock's (2010) call for more research of the individual in hybrid and culturally diverse cities from which the postsecular emerges. Havlicek and Klingorova's (2017) survey of public 'sacred sites' found within postcommunity Prague illustrates the prevalence of religion and its materialities in otherwise (and historically reinforced) secular urban space, and in the process accruing new function and meaning for the city, and its residents and visitors. In Jerusalem, residents of conservative neighbourhoods impose religious values relating to modest clothing in the area with (illegal) 
signs and regulation, reclaiming and territorializing secular public space (Fenster 2011). In a recent article, della Dora argues for 'infrasecular geographies' of sacred spaces transformed, modified, or 'unmade' into secular space, yet retain the visual expressions of religion, contending her term is effective 'in capturing the complexity of a society in which the secular and the religious coexist, overlap and compete' (2018: 48). In the context of the city, the postsecular has 'crossed the boundary, made incursions and inroads, and arguably begun to transform its secular host' (Knott 2010: 28). Beaumont and Baker (2011) discuss the 'spiritual re-appropriation' of the secular landscape in the context of organizations that resist secular neoliberal claiming of the city. Following on from Havlicek and Klingorova's survey of publicly visible 'sacred sites', the territorializing of urban neighbourhoods (Fenster 2011), and an embodiment perspective, the research presented here focuses on the postsecular space and spatialities of the body.

\section{Religion and mobility}

Geographers of religion and spirituality have also engaged with the new mobilities paradigm and the call by Kong for research beyond the official borders and sites of faith to understand " $[t]$ he ways in which religion is experienced and negotiated are also multifaceted and multiscaled, from the body to the neighbourhood, city, nation, and across nations' (2001: 769). The new mobilities paradigm recognizes the centrality of mobility to contemporary social life (Urry 2007): who or what is moving, what speed are they moving, how are they moving, where are they moving. Everyday movement encompasses multitudes of social life and can bring travellers into encounters with a diverse range other people, objects, and places. Additionally, mobilities research has uncovered a range of activities and strategies that drivers, passengers, pedestrians, and other travellers employ to increase the enjoyment or utility of their travel time. 
While geographers of religion have engaged with mobility, traditionally this has been focussed on the area of pilgrimage: extraordinary journeys perceived to be difficult, expensive, and arduous. More recent literature has challenged this perception and investigated the socioeconomic continuities with everyday life within contemporary pilgrimage (for example, Eade and Sallnow 1991; Coleman and Eade 2004). Maddrell et al. (2015a)-edited collection Sacred Mobilities potentially introduces a new dimension to this research that understands the significance that movement can enable to a diverse range of secular-sacred spaces. The editors' own contribution (2015b) to the collection, a chapter regarding the annual TT motorbike races in the Isle of Man, underlines their interpretation of sacred spaces as inclusive of secular events. This research reflects innovative approaches to understanding the space between religion and the secular dimensions of social life.

Mobility has also featured, if less explicitly, in other studies since the turn of the twenty-first century. The practice of spirituality and activities, such as yoga and meditation, originate in spiritual or religious contexts, in and amongst everyday life and habits (Holloway 2003; MacKian 2012; Philo et al. 2011, 2015). Such studies have addressed the shift of religion and spirituality from institutionally focussed to individually centred approaches to developing a set of practices and beliefs that are relevant to and draw from personal experience (Heelas and Woodhead 2005; Giordan and Pace 2012). In the process, religion and spirituality have continued significance yet simultaneously reduced visibility in the public sphere. Instead, religion and spirituality have moved beyond traditional boundaries into everyday spaces from urban parks to driving spaces, merging the secular and the religious. While these studies have been very fruitful, engagement with mobilities is still a relatively growing area, and, in addition, the focus on non-institutional religion has unduly emphasized alternative spiritual and holistic 
practices rather than subjectively constructed experiences of mainstream religions such as Christianity. These practices demonstrate an emerging approach of combining official and unofficial practices and beliefs and suggest new approaches to understanding the postsecular. This research addresses these issues and explores how spiritual and religious ideas and practices are realized in the daily lives of participants—especially in those time-spaces considered as secular and outside of the coding, regulation, and maintenance of the 'official spaces' of religion, in this case the Baptist church or Buddhist meditation centre of Bristol. This work understands the postsecular set of relations on the scale of the individuals, as they practice and perform actions that enable their spirituality to emerge in otherwise secular spaces.

\section{Methods}

The empirical work presented in this essay investigates the subjective experience of combining the spiritual with the secular in time-spaces of mobility. The sample was therefore drawn from two groups that represent the 'congregational domain' and the 'holistic milieu' as mapped by Heelas and Woodhead (2005) to explore how both a traditionally embedded congregational sample and a holistic sample adapt to time-spaces of mobility. The Baptist Christian denomination was selected as an example of the congregational domain, whilst Buddhist meditation centres were selected from the holistic milieu. Many of the participants did identify themselves as 'Baptist Christians' and 'Buddhists'; however, this was not a requirement of the research. The participants were selected as people who attended sites of Christian worship or Buddhist-led meditation whether or not they affiliated with the broader religious movement. Participants, recruited via a survey earlier in the research, were asked to keep a diary of their activities for one week and then discuss this in the context of an interview. 
Similar to Cadman et al (2013), the project sought out the time-spaces in which religion and spirituality 'structure, frame and bleed into everyday practices', necessitating ethnographic research to be undertaken. A diary-interview method was employed to allow access to the personal experiences of the participant without the disruption of a researcher. Diaries enabled an intimate portrait of the participant's to be developed; the interweaving of their spiritual lives and their secular lives while the interviews that accompanied the diaries in this research were semistructured, usually lasting around one hour in duration. The interview provided an opportunity to clarify activities and to increase the resolution of data from generic terms of 'walking' to 'walking to work, thinking about $x$, acting in this way because of $y$ ', deepening the diary data (Phipps and Vernon 2009). Along with the diaries, thorough thematic analysis was carried out on the participant's corresponding interview transcript. In total, 16 sets of diaries and interview transcripts were collected, coded, and analyzed for themes emerging from their everyday journeys and spiritual practices. All participants have been assigned pseudonyms to maintain their confidentiality whilst survey respondents are left unnamed. Church and meditation centre names have also been changed for this reason.

\section{Postsecular spaces of the everyday}

This section examines the participant's use of particular places and times for spiritual or religious purposes within the socio-economic schedule of everyday life. It explores the participant's practice of religion and spirituality within environments considered to be public and secular in identity. In doing so, the diminishing distinctions between religion and the secular, the sacred and profane, are examined. While recognizing that these modes are not polarized in everyday life but blended into each other, this research asserts that there is an affinity between the two modes of space that allows participants to negotiate this pairing within the modern environments in 
which they are positioned. Within these spaces, the engagement of socio-economic responsibilities of everyday life synchronises and supports the rhythmic, behavioural, and mental manifestations of religious and spiritual activity among participants. Such synergies act to generate additional meaning and significance for the participant as the two rhythmic sources interact and adjust to each other.

The temporary time-spaces that participants construct or manipulate in otherwise transient spaces, those of employment and leisure are identified and explored here. These time-spaces do not 'belong' to, nor are specially constructed for, the participant, yet they are able to use these spaces for prayer and meditation activities before they are returned to normal use. As they create space-time paths throughout the day, from waking up in the private space of their bedroom in the morning to returning to the same room at night, the individuals thread together a range of timespaces within their everyday spatial range and activities. For participants in this research, these spaces can also accrue meaning through the practices and performances enacted. These public spaces are usually considered as 'secular', such as the workplace, the mobility-centred spaces of a journey, and the recreational spaces of parks, amongst other places.

These spaces contain specific circumstances that can influence the form of religious or spiritual activity practised or drawn upon. Pockets within employment time-spaces could be transformed, temporarily, into spaces of renewal and spiritual practice, and this occurred with several participants. Paul and Richard of the meditation centre sample, for example, developed strategies and networks to accommodate brief moments of meditation practice throughout their working day. Paul made time for a series of two-minute meditations at certain points throughout the day, while Richard had found a quiet room at his workplace for brief moments of meditation. Throughout his participation in this research, it was clear his job was a significant source of 
stress and anxiety to Richard. When he could anticipate heightened stress levels or a greater level of commitment to his meditation, Richard would also carry with him an MP3 player to aid his practice, containing audio files for meditation practice including a recording by Jack Cornfield, a well-known teacher within Theravada Buddhism. As well as this room at work, Richard also sought to use opportunities presented within his working and travel schedule for brief pockets of meditation practice:

I'm pretty good in traffic jams. [...] and sometimes actually it's an opportunity [...] I think well here's an opportunity [for breathing exercises]. If I get somewhere early think well I can get out of the car and go and sit in there and scrounge a cup of tea or...I can sit here for ten minutes and shut my eyes and do a sort of breathing, slow myself down.

Here, Richard has identified time-spaces that are often negatively perceived — sitting in a traffic jam and the tedium or anxiety of waiting for a meeting — and transformed these for positive effect using meditative practice.

Unlike Richard and Paul, who removed themselves from other people and sources of distraction for spiritual practices, Michelle found a benefit in remaining at her desk and using podcasts on Buddhist meditative instruction and teachings in the background while working, finding that the occasional comment will disrupt the working body:

\section{And then you pick up snippets. You think oh yeah, god they've got a point there, let me try it. \\ $[\ldots]$ But you always, you kind of tend to go back to your old habits but that's the whole point isn’t it? Eventually you won't.}

Michelle's final comment here makes visible an underlying theme also present within Richard's and Paul's accounts: the attempt to alter pre-established and continually reproduced habits. Paul 
has embedded a new habitual routine within his working schedule to pre-empt employmentrelated stresses and anxieties. Richard aims to transform time-spaces that are likely to lead to frustration and tedium, such as traffic jams and waiting around, into positive opportunities for renewal. Michelle acknowledges the challenging nature of changing habits, but uses podcasts and practice to try to affect change. Diverging from Philo et al.'s (2015) participants, Michelle, Richard, and Paul, along with other participants in this sample, embed their individual spiritual practices within the time-spaces that are likely sources of stress and anxiety in an attempt to control their response to the stimuli accommodated by these environments.

Spiritual practices during work hours amongst the Baptist church sample were also observed during this research. However, these were manifested with a greater degree of spontaneity and in many respects greater level of embedding into the events and surroundings of the day. Spiritual activities manifested themselves in these environments in the forms of brief prayers that could be uttered or contemplated at the desk in between workloads and tasks.

\section{Max: $[\ldots]$ It tends to be when there's particular issues coming up and then they crop up in} your mind in the day so yeah. Prayers are a kind of amorphous thing.

Max's comments and similar remarks by other participants from the Baptist Church sample imply a wave-like quality to prayer and spiritual practice, catalyzed by internal and external stimuli throughout the day. More overtly communicated here than with the earlier examples from meditation centre participants is the sense that prayer emerges and dissolves into the fabric of daily activities seamlessly as a stream of consciousness. That Max (and other participants from the Baptist church sample) recognizes moments of prayer implies the embeddedness of this practice even though it does not require specifically codified spaces, behaviours, or gestures. 
Prayer, moments of meditations, or listening to Buddhist teachings or instructions are practices which originate and are imported from the participant's involvement with Buddhist meditation centres - a transfer from 'official' spaces of the meditation centre to the 'unofficial' spaces that the participant inhabits in everyday life. The practice contains the original intention of bringing contemplation, mindfulness, or calmness, but is modified in format to fit in with the participant's secular socio-economically shaped requirements. Such seamless integration of religion and secular activities resonates with Beaumont and Baker's (2011) assertion that religion mimics the designs and flows of neoliberal urban spaces. In turn, the manifestation of the religious or the spiritual within the secular everyday creates new meaning as the practice helps the participant to find the relevance of the sacred within the profane. The religious and the spiritual emerge and transform the secular (Knott 2010) space of the workplace, allowing a postsecular identity to emerge in the thoughts and practices of the individual through their prayers, meditations, and contemplations.

Experiences of participants utilizing everyday spaces for religious or spiritual purposes were not restricted to places of work. Across both samples, there were numerous reports of everyday spaces of leisure being employed by participants for a form of renewal. These most often consisted of public green spaces across the city. The theme of renewal for the majority of accounts was centred upon a communion with nature and natural environmental processes. Michelle, for example, spoke at length about the renewing effects of green spaces where natural cycles of birth, growth, decay, and death could be observed. 
usually when I'm feeling...that I need resourcing then I, then I can feel when I walk through

the park it gives me something back.

Michelle speaks here of seeking out specific sites that can 'resource' her, echoing the need of participants for pockets from which to draw 'energy' within everyday public space (Philo et al. 2011, 2015). Aesthetic value could also be identified in the human-constructed landscape; however, for Michelle, there was a distinct difference in the 'resourcing' effects of the natural over the human landscape:

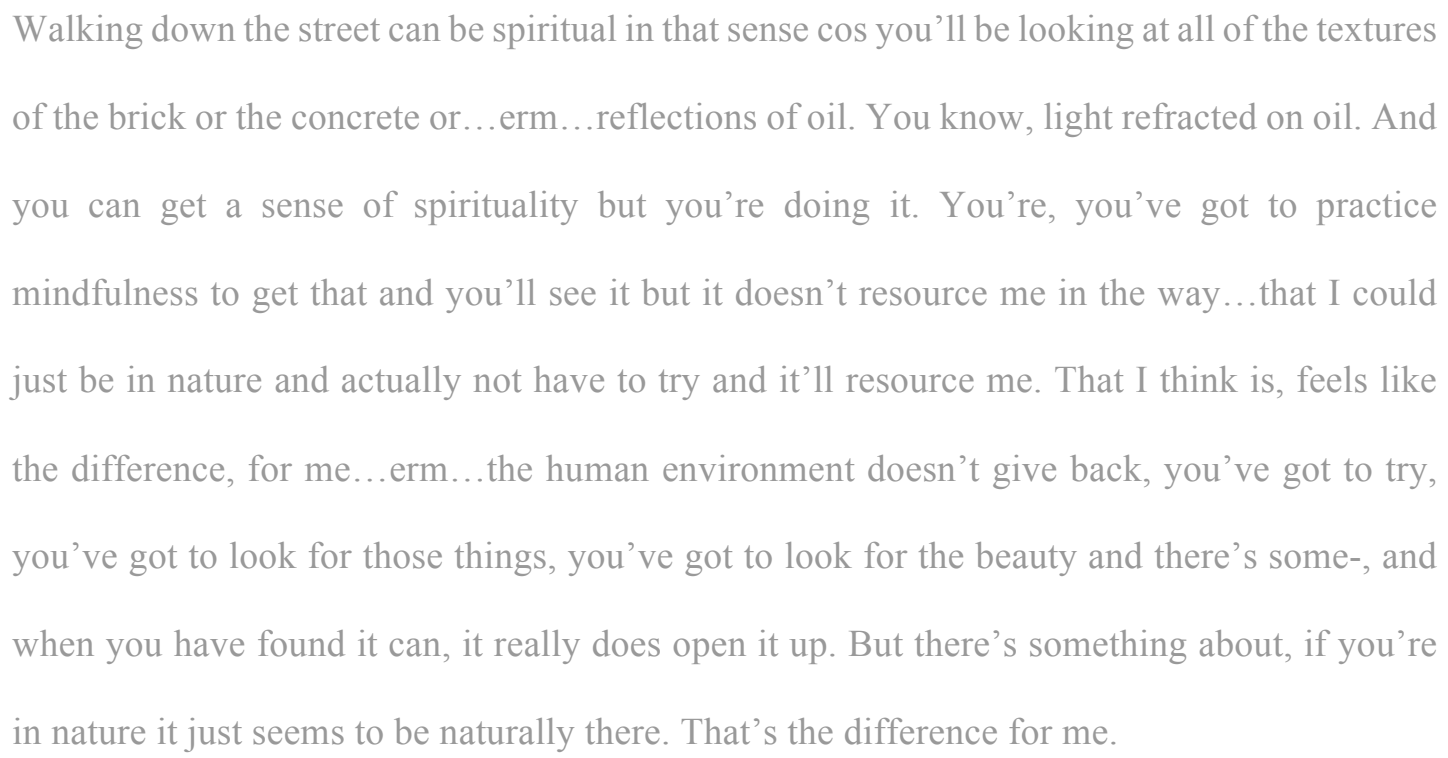

Rhythms of nature that are allowed into the urban environment command a restorative effect and energy that can be drawn upon by the individual. The cycles of death and rebirth that are present within nature are present within green spaces rather than the impermeable surfaces of the concrete streets. Rhythms of nature intersect with the rhythms of daily life for this participant, slowing down the pace of her otherwise busy life (Wunderlich, 2013) to enable moments of rejuvenation. 
Modern surfaces, in Michelle's account, are 'impermeable' and non-reactive compared with 'natural' surfaces, although not entirely absent of 'resourcing' capacity. The overall theme here of the restorative effects of natural rather than human spaces echoes similar conclusions from environmental psychologists (Maddrell and della Dora 2013) — a sense of enchantment that recharges the recipient (Bennett, 2001; Philo et al. 2015). Despite the impermeable appearance of modern environments, Michelle was able to identify natural processes of erosion and decay within the urban fabric. Landscapes that are perceived as durable and stable are also subject to natural processes of degeneration and regeneration. Such observations here echo Beckford's (2012) suggestion that a revival of enchantment in the world and shift away from the twentieth century's singular focus on technology and rationality (Beaumont and Baker 2011) are part of the emergence of postsecular landscapes.

Another participant from the meditation centre sample, Sean, talked of 'awareness' when outside in physical movement or in the pauses between physical movements. This awareness could often be linked to the mobility he was directly engaged in, such as cycling along motorized traffic-free routes, for example, a former railway path that had been converted to a dedicated pedestriancycle path:

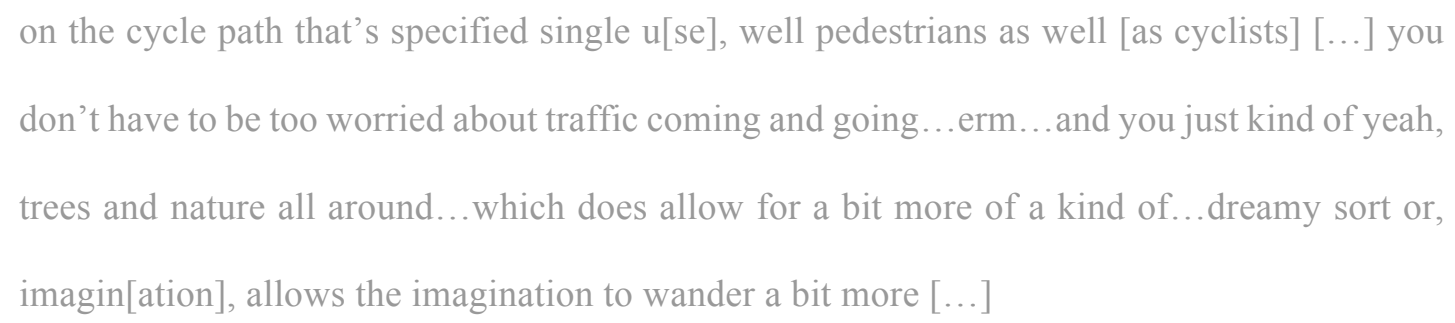

The separation of motorised and non-motorized traffic in this park provides the protection from the dangers of the road. Similarly, the separation of churches and meditation spaces from the outside world enables participants to feel comfortable and secure enough to engage in activities 
where they may otherwise feel vulnerable. In this case Sean is able to let the imagination wander. Sean, like Michelle, could also see a form of aesthetic beauty in the built environment to a certain extent:

in town there's still room for the imagination to wander. Sort of into shop windows or into people passing you or I don't know whatever you're doing. Yeah I think that's sort of...there's something about the, pedestrianism that...erm...I guess lends itself a bit to...just to a bit more sort of...erm....an open awareness?

Within these quotes and their interviews, Michelle and Sean interpret the urban environment through their own spiritual framework. The use of terms such as 'mindfulness', 'resourcing', and 'awareness' can be traced to the discourse of the holistic milieu. Participants here are able to find pockets within everyday public space which fulfils a spiritual purpose, re-energising their day. This use of space, particularly of urban parks, was not limited to the Meditation Centre sample but also present within the Baptist Church participants' experience as well. Rita had developed a specific form of practice that encompassed her cycling through a park on the way to work in the mornings she called a 'cycling liturgy' (see Wigley 2018). Through the reciting of prayer and scripture at specific marker points in the park, her experience of the place had changed as these words had become embedded within the landscape. On another morning during her diary week and in a different park, on her way to the local supermarket, Rita described an awareness of being 'alone with God'. The interview probed this comment further and found this feeling was partially stimulated at least by the temporary cessation of socio-economic duties, and the language which she employed was spirituality-centred. Protestant denominations such as the Baptists traditionally reject the idea of certain spaces allowing for increased access to God based on the eternal and all-pervading presence. Rita frames this connection to God in this park as 
'being alone' rather than necessarily being closer; hence, it may be that as distractions fade into the background and the sensory field changes from one of a human-constructed to a natural (if ultimately humanly engineered) environment, that God occupies more of the believer's perceptive field.

Urban space is often associated with the concrete greyness of roads and buildings as part of a secular, neoliberal, and mundane environment. Green spaces, usually parks but also cycle paths, appear to be spaces where the participants could find a connection with a higher, underlying power. These spaces open up the urban greyness and the impermeable character of concrete and private-owned properties that alienate the individual. Nature imposes its rhythms through the sense channels of sound, vision, smell, and touch, reminding the individual of the transcendent cosmic processes that underlie artificial surfaces, enabling a postsecular landscape to emerge, recognizing enchantment in everyday life (Beckford 2012, even if he objects to the term). Distinctions between religion and secular become blurred and challenged (Knott 2010) as 'secular' public spaces are appropriated for spiritual practices rooted in Christian and Buddhist traditions. In such spaces, a sense of a transcendent reality accessible within the mundane secular realm leads to an emergence of the postsecular as bringing together the spiritual and the secular in coexistence.

\section{Conclusion}

This contribution has drawn upon empirical material to illustrate the potential for modern urban and economic landscapes to afford opportunities for spirituality and religion, as well as be transformed in the perceptions of those actors who utilize the environment. Spaces and places of work and of leisure have been explored in the experiences of the diary participants, and their uses of these spaces have revealed a spiritual depth that has been constructed in spaces built on 
secular values. It is not simply that participants used their places of work to engage in meditation, for example, as a means of supporting their economic or productive activity but that these spaces are used as opportunities to further spiritual development, to disassemble habits they consider to be impediments for well-being. Similarly, the parks or the cycle paths provide breaks within modern rhythms of movement, mobility, and activity, enabling the participants here to reconnect with a spiritual awareness.

Activities and practices of these participants are relatively silent or not-outwardly obvious to external audiences. Their diaries do not reveal any confrontations or challenges despite these practices often taking place in public or shared spaces and visible to friends, family, colleagues, or strangers. The practices have escaped from the 'official' spaces of the meditation centre or the church, but are equally not confined to the private spaces of the home as secularist and secularisation theory would imagine. These practices blend or complement otherwise secular actions such as walking, cycling through parks, or sitting in traffic jams. They merge into and 'spiritually appropriate' (Beaumont and Baker 2011) everyday routines as the gap between the religious/spiritual and the secular enables a postsecular experience at the heart of a subjective spiritual geography of urban time-spaces.

\section{Further reading}

della Dora, V. (2018) 'Infrasecular geographies: making, unmaking and remaking sacred space', Progress in Human Geography, 42(1): 44-71.

Provides an up-to-date review of the postsecular literature while also offering a new concept of 'infrasecular' geographies that capture the rich layering of sacred and secular spaces in Western societies.

Gökarıksel, B. and A. Secor (2015) 'Post-secular geographies and the problem of pluralism: Religion and everyday life in Istanbul', Political Geography, 46: 21-30. 
Study of Muslim women in Istanbul as they encounter and coexist with secular and Alevi neighbours, investigating the lived experience of pluralities on the scale of the body.

\section{References}

Beaumont, J. and C. Baker (eds.) (2011) Postsecular Cities: space, theory and practice, London: Contiuum.

Beckford, J. A. (2012) 'SSSR presidential address: public religions and the postsecular: critical reflections', Journal for the Scientific Study of Religion, 51(1): 1-19.

Bennett, J. (2001) The Enchantment of Modern Life: attachments, crossings, and ethics, Princeton: Princeton University Press.

Bruce, S. (2013) 'Post-secularity and religion in Britain: an empirical assessment', Journal of Contemporary Religion, 28(3): 369-84.

Cadman, L., Philo, C. and J. Lea (2013) 'Using time-space diaries and interviews to research spiritualities in an everyday context'. In Woodhead, L. (ed.) How to Research Religion: putting methods into practice, Oxford: Oxford University Press.

Cloke, P. (2011) 'Emerging postsecular rapprochement in the contemporary city'. In Beaumont, J. and C. Baker (eds.) Postsecular Cities: space, theory and practice, London: Continuum.

Cloke, P. and J. Beaumont (2013) 'Geographies of postsecular rapprochement in the city', Progress in Human Geography, 37(1): 27-51.

Coleman, S. and J. Eade (2004) 'Introduction: reframing pilgrimage'. In Coleman, S. and J. Eade (eds.) Reframing Pilgrimage: cultures in motion, London/New York: Routledge.

Dalferth, I. U. (2010) 'Post-secular society: Christianity and the dialectics of the secular', Journal of the American Academy of Religion, 78(2): 317-45.

Davie, G. (1994) Religion in Britain since 1945: believing without belonging, Oxford: Blackwell.

- (2006) 'Religion in Europe in the 21st century: the factors to take into account', European Journal of Sociology, 47(2): 271-96.

- (2015) Religion in Britain: a persistent paradox, Malden MA: Wiley-Blackwell.

Eade, J. and M. J. Sallnow (1991) 'Introduction'. In Eade, J. and M. J. Sallnow (eds.) Contesting the Sacred: the anthropology of Christian pilgrimage, London: Routledge. 
Fenster, T. (2011) 'Non-secular cities? Visual and sound representations of the religious-secular right to the city in Jerusalem'. In Beaumont, J. and C. Baker (eds.) Postsecular Cities: space, theory and practice, London: Continuum.

Giordan, G. and E. Pace (2012) 'Introduction: mapping religion and spirituality in a postsecular world'. In Giordan, G. and E. Pace (eds.) Mapping Religion and Spirituality in a Postsecular World, Leiden/Boston, MA: Brill.

Guest, M., Olson, E. and J. Wolffe (2012) ‘Christianity: loss of monopoly'. In Woodhead, L. and R. Catto (eds.) Religion and Change in Modern Britain, Abingdon: Routledge.

Harvey, G. and G. Vincent (2012) ‘Alternative spiritualities: marginal and mainstream’. In Woodhead, L. and R. Catto (eds.) Religion and Change in Modern Britain, Abingdon: Routledge.

Havlicek, T. and K. Klingorova (2017) 'City with or without God? Features of post-secularism in religious landscape of post-communist Prague', Social \& Cultural Geography, doi: 10.1080/14649365.2017.1312696, accessed online 16-06-2018.

Heelas, P. and L. Woodhead (2005) The Spiritual Revolution: why religion is giving way to spirituality, Oxford: Blackwell.

Holloway, J. (2003) 'Make-believe: spiritual practice, embodiment, and sacred space', Environment and Planning A, 35(11): 1961-74.

Knott, K. (2005) The Location of Religion: a spatial analysis, London/Oakville: Equinox Publishing Ltd.

- (2010) 'Cutting through the postsecular city: a spatial interrogation'. In Molendjik, A. L., Beaumont, J. and C. Jedan (eds.) Exploring the Postsecular: the religious, the political and the urban, Leiden/Boston, MA: Brill.

Kong, L. (2001) 'Mapping “new” geographies of religion: politics and poetics in modernity', Progress in Human Geography, 25: 211-33.

MacKian, S. (2012) Everyday Spirituality: social and spatial worlds of enchantment, Basingstoke: Palgrave Macmillan.

Maddrell, A. and V. della Dora (2013) 'Editorial: spaces of renewal', Culture and Religion, 14(1): $1-7$.

Maddrell, A., Terry, A. and T. Gale (2015a) Sacred Mobilities: journeys of belief and belonging, Farnham: Ashgate. 
Maddrell, A., Terry, A., Gale, T. and S. Arlidge (2015b) 'At least once in a lifetime: sports pilgrimage and constructions of the TT races as "sacred" journey'. In Maddrell, Terry, A. and T. Gale (eds.) Sacred Mobilities: journeys of belief and belonging, Farnham: Ashgate.

Molendjik, A. L., Beaumont, J. and C. Jedan (eds.) (2010) Exploring the Postsecular: the religious, the political and the urban, Leiden/Boston, MA: Brill.

Olson, E., Hopkins, P., Pain, R. and G. Vincett (2013) 'Retheorizing the postsecular present: embodiment, spatial transcendence, and challenges to authenticity among young Christians in Glasgow, Scotland', Annals of the Association of American Geographers, 103(6): 1421-36.

Parsons, G. (1993) 'Contrasts and continuities: the traditional Christian churches in Britain since 1945'. In Parsons, G. (ed.) The Growth of Religious Diversity: Britain from 1945, London: Routledge. pp. 23-94.

Philo, C., Cadman, L. and J. Lea (2011) The everyday urban spiritual: placing spiritual practices in context (Working Paper). University of Glasgow: Religion and Society.

- (2015) 'New energy geographies: a case study of yoga, meditation and healthfulness', Journal of Medical Humanities, 36: 35-46.

Phipps, P. A. and M. K. Vernon (2009) 'Twenty-four hours: an overview of the recall diary method and data quality in the American Time Use Survey'. In Belli, R. F., Stafford, F. P. and D. F. Alwin (eds.) Calendar and Time Diary, London: Sage.

Reynolds, N. (2015) 'Discourses of love, compassion, and belonging: reframing Christianity for a secular audience', Journal of Contemporary Religion, 30(1): 39-54.

Stevenson, D., Dunn, K., Possamai, A. and A. Piracha (2010) 'Religious belief across "postsecular" Sydney: the multiple trends in (de)secularisation', Australian Geographer, 41(3): $323-50$.

Urry, J. (2007) Mobilities, Cambridge: Polity.

Wigley, E. (2018) 'Constructing subjective spiritual geographies in everyday mobilities: the practice of prayer and meditation in corporeal travel', Social \& Cultural Geography, 13(3): $411-25$.

Wilson, E. K. and M. B. Steger (2013) 'Religious globalism in the post-secular age', Globalizations, 10(3): 481-95.

Woodhead, L. (2012) 'Introduction'. In Woodhead, L. and R. Catto (eds.) Religion and Change in Modern Britain, Abingdon: Routledge. 
Wunderlich, F. M. (2013) 'Place-temporality and urban place-rhythms in urban analysis and design: an aesthetic akin to music', Journal of Urban Design, 18(3): 1-26.

Zock, H. (2010) 'Voicing the self in postsecular society: a psychological perspective on meaning-making and collective identities'. In Molendjik, A. L., Beaumont, J. and C. Jedan (eds.) Exploring the Postsecular: the religious, the political and the urban, Leiden/Boston, MA: Brill. 